\title{
Development of Students' Pedagogical Abilities through Socio-Psychological Training
}

\author{
https://doi.org/10.3991/ijet.v16i16.23335 \\ Araily Shakirova ${ }^{1}(\varpi)$, Galina Romanova ${ }^{2}$, Svetlana Vlasova ${ }^{3}$ \\ ${ }^{1}$ Zhetysu University named after I. Zhansugurov, Taldykorgan, Kazakhstan \\ ${ }^{2}$ Academy of Social Management, Moscow, Russian Federation \\ ${ }^{3}$ Moscow Aviation Institute, Moscow, Russian Federation \\ shakirovaara@rambler.ru
}

\begin{abstract}
The research is devoted to the study of the effect of sociopsychological training on the development of pedagogical abilities when preparing teachers. The study involved 88 full-time five-year students of the Academy of Social Management (Moscow) and four-year students of Zhetysu State University named after I. Zhansugurov (Taldykorgan). The goal was achieved based on a system of special tasks within socio-psychological training sessions. The experiment and research were carried out for six months. In order to achieve reliable results, the standard deviation in the sample and the Student's t-test were calculated for the experimental and control groups. The study revealed that the influence of socio-psychological training is effective for the development of students' communication skills as the mean values obtained by experimental group respondents were higher than those of the control group. In parallel, the examination outlined a weak positive relationship between age and pedagogical abilities $(r<0.2)$ and somehow better positive correlation between gender and pedagogical abilities ( $r>0.3$ ). This suggests that gender and age have no considerable impact on the development of pedagogical abilities among students. Favorable prospects were satisfied only for the effect of regular sociopsychological training sessions - they were defined as capable of improving the pedagogical abilities of future educators. The results of this work can be of interest to teachers of universities and training centers, as well as students trained as future educators.
\end{abstract}

Keywords—communication skills, empathy, pedagogical abilities, pedagogical tact, socio-psychological training

\section{Introduction}

In the context of improving educational technologies and the globalization of education, there are new requirements for teacher training. Along with professional knowledge and skills, employers value such new competencies as leadership qualities, the ability to work in a team, a creative approach to the solution of educational problems, and the ability to learn and adapt to changes $[1,2]$. The structure and content of the professional and personal development of a student have been studied by many 
researchers in sociological, psychological, and pedagogical contexts [3]. Ability to understand and accept oneself as a teacher is widely regarded as an important factor in professional and pedagogical development of a future educator. It is on this basis all other components of professional and personal requirements for the teacher personality can be formed $[4,5]$. The approval of the professional standard for teachers suggests the need for changes in the organization, content, and technology of teacher training, as well as an expanded assessment scale [6].

\subsection{Pedagogical abilities}

The development of important professional qualities in students is largely determined by the purposeful and well-organized activities of the university, an important aspect of which is the development of pedagogical abilities in young teachers throughout the learning process [7]. Students' pedagogical abilities are considered as learning outcomes, expressed in the capability to solve important professional tasks and find alternatives to address professional problems or make the best choice [8].

Pedagogical skills hold a unique position in the structure of the teacher's personality along with pedagogical competence and pedagogical excellence. Pedagogical abilities are defined as a combination of personal psychological characteristics and important professional qualities of a teacher that ensure the achievement of positive results in pedagogical activity $[9,10]$. The difference between pedagogical abilities and pedagogical skills lies in the fact that pedagogical abilities are personality traits while pedagogical skills are defined as separate acts of pedagogical activity carried out by a person at a high level. The most important components of pedagogical abilities are managerial and communication skills, pedagogical tact, and observation [11]. The leading role is played by communication skills and pedagogical tact. An important aspect of the communication skills of the teacher is readiness for empathy, namely, for understanding the mental state of students [12]. Empathy helps the teacher to gain an insight into the child's inner world, mentally take his/her position, and empathize. The ability to understand the feelings of a child is important for the teacher [13]. The major tasks of the successful development of the teacher's communication skills cover social interaction, establishing friendly relations with students, carrying out pedagogical communication properly, being tactful, showing compassion and cordiality, and combining rigor with a respectful attitude towards students [14]. Pedagogical tact is manifested from the first to the last minute of contact with children; it determines the culture of the relationship between them and contributes to the greatest educational effect. In general, pedagogical tact is based on the understanding of child psychology, respect for their personality, sensitivity, attentiveness to the mental state, and equal treatment. A high level of pedagogical tact allows educators to overcome negative stereotypes and attitudes when recognizing students' personal qualities and avoid conflict situations in the educational process $[15,16]$. Managerial skills, in turn, are important for the rational management of individual and group educational and extracurricular activities of students, as well as the activities of the teacher [17].

As such, education allows one to meet the goals of qualification, subjectivation, and socialization. In this respect, pedagogical tact is an essential quality for achieving each 
of them [16]. The effectiveness of the educational process also depends on the teacher's observation skills since they allow perceiving student's mental qualities adequately and enable the assessment from both general and individual perspectives. Not less important and essential requirement is to love the very teaching job [18].

\subsection{Socio-psychological training}

A future teacher should understand and apply information and innovative pedagogical technologies. Traditional methods of instruction are taking a back seat, and various forms of active learning are gaining increasing popularity, in particular in the field of psychological services [19,20]. As a rule, classes are referred to as a form of active learning that aims to create the interpersonal component of professional activity through the development of a psychodynamic and professional environment, which determines further development of the individual by means of integration and immersion [21]. The most popular form of active learning is training. It is a method of preparation directed at developing practical skills and knowledge by completing sequential tasks and actions. The teacher gets an opportunity to provide participants with essential information and allows students to develop professional behavior while performing assignments $[22,23]$. In the process of teachers' preparation, psychological training holds a unique position; it is defined as active learning through the acquisition and comprehension of life experience, which is modeled in interpersonal interaction and is realized during the discussion [24]. Socio-psychological training is focused on the acquisition and improvement of skills related to supporting the process of solving a group problem. Its implementation is always carried out within a social group and uses the dynamics of this group, as well as the processes that occur in it [25]. Socio-psychological training can be performed based on different methods aimed at the development of the pedagogical abilities of students. The most common are role-playing/business games and group discussions (a case study or group analysis) [26]. Socio-psychological training is an effective tool for the development of socio-communicative abilities when preparing teachers (psychological sensitivity, contact, the ability to navigate in difficult interpersonal situations) [27]. One of the prerequisites for the success of training is reflection, which is constantly carried out in the course of classes and shows the effect of attitudes on the level of mastery of skills and abilities [28]. When planning training, it is considered a bad practice to mix different tasks within the same training group. This can reduce its effectiveness and cause ethical problems as, during the prepaprtion, the task can be changed only with the consent of the group [29].

The high educational effectiveness of socio-psychological training is also determined by the fact that it is based on modeling real situations and requires active involvement of participants in the process of communication and mobilization of intellectual and analytical potential. In the learning process, participants develop the most productive practices and ways of interaction taking into account the individual characteristics and abilities of the student [30]. The training session should start with an easy warm-up and then move to the major tasks. All participants should take an active part in it; show goodwill and complete trust in each other; be open and sincere; abandon 
common phrases; evaluate actions, behavior, and communication rather than personality; listen to the opinions and advice of group members, consider them, but make decisions on their own; and convey the impressions of the participants and their level of satisfaction with the process [31].

The relevance of the problem of the development of pedagogical abilities, lack of theoretical and methodological strategies, the practical need to improve the quality of preparing teachers have determined the goal of this study.

\section{$2 \quad$ Material and method}

\subsection{Research design}

The experiment and research were conducted at the Academy of Social Management located in Moscow and Zhetysu State University named after I. Zhansugurov located in Taldykorgan. The purpose of the study was to examine the process of developing students' pedagogical abilities through socio-psychological training. To achieve this goal, the following tasks were set:

1. To determine the level of students' pedagogical abilities before and after the experiment.

2. To organize and conduct socio-psychological training sessions.

3. To determine the impact of training sessions on the pedagogical abilities of students.

The ultimate study goal was achieved based on a system of special tasks and sociopsychological training sessions. The experiment and research were carried out for six months. During this period, two groups of participants with an equal number of students $(\mathrm{N}=44)$ were singled out. Both of them were equally treated in terms of the educational objectives, content, and material. The only difference lay in the fact that the experimental group took part in socio-psychological training while the control one followed the traditional training pattern based on lectures, seminars, and practical assignments. At the initial stage, the training schedule was determined, and the methodology of the work was discussed. The purpose of the study was explained, and the students were familiarized with the work plan. Besides, the norms of behavior during the socio-psychological training activities crucial for the success of the chosen preparation method were established. At the final stage, tests and questionnaires were conducted to determine the role of the proposed socio-psychological training sessions. The research became possible thanks to the deans of the faculties, as well as the curators of the groups.

\subsection{Data}

To analyze the development of pedagogical abilities through socio-psychological training, the pre- and post-tests were carried out. Based on the literature analysis, we identified the following key pedagogical abilities: communication skills, the ability to understand the student, and pedagogical tact. 


\subsection{Instruments}

To determine communication skills, the Assessment of Self-Control communication test (M. Snyder) was used [32]. It is a set of 10 statements that students assess as true or false based on their opinion. One point was given for "False" responses to question $1,5,7$, and "True" responses to the others. Based on the answers, there were three levels of sociability: 0-3 points - low; 4-6 - medium; 7-10 -high.

To study the ability to empathize and understand child feelings, we used the SelfAssessment of Empathic Abilities test by Mehrabian and Epstein [33]. It consisted of 25 closed questions of both direct and reverse types. The participants should assess the degree of their agreement/disagreement with each of them. The scale of responses ranged from "strongly agree" to "strongly disagree". Based on the results obtained, there were also three empathic abilities levels: 63-90 points — high level; 37-62 average; $36-0$ - low;

To determine the pedagogical tact level, we used the "Have you developed pedagogical tact" test modified by R.R. Kalinina. The test consisted of 24 questions that respondents had to agree or disagree with. The questions are given in Table 1. The research methods used allowed us to distinguish three levels of pedagogical abilities: low, high, and average, with the points distributed as follows: 24-18 points - high level; 17-12 points - average; 12-0 points - low level.

Table 1. The assessment of communication skills in the sample

\begin{tabular}{|l|c|c|c|c|}
\hline & \multicolumn{2}{|c|}{ Pre-test } & \multicolumn{2}{c|}{ Post-test } \\
\hline & Experimental group & Control group & Experimental group & Control group \\
\hline Average test value & 4.81 & 5.01 & 8.32 & 5.91 \\
\hline Standard deviation & 0.03 & 0.05 & 2.14 & 1.73 \\
\hline $\mathrm{p}$-value & \multicolumn{2}{|c|}{0.061} & \multicolumn{2}{c|}{0.023} \\
\hline
\end{tabular}

\subsection{Participants}

The study involved 88 full-time five-year pedagogical students of the Academy of Social Management (Moscow); there were 45 female and 43 male participants aged 22 $(\mathrm{N}=31)$ and 23 years $(\mathrm{N}=57)$. The error rate is almost $3 \%$.

\subsection{Ethical issues}

The research participants took part in the study voluntarily on the condition of anonymity. No personal data were collected, stored, or used during the study.

\subsection{Data analysis}

The results were analyzed based on the cross-sectional descriptive and comparative statistical analysis. The statistical data were processed in Statsoft Statistica V. 6.0 and analyzed in SPSS Statistics V.10. Microsoft Excel was used to visualize the data. The 
sample standard deviation and the Student's t-test $(\mathrm{p}<0.05)$ were calculated for the experimental and control groups. Thus, the null hypothesis that the use of socio-psychological tests does not affect the development of pedagogical abilities was tested. Correlation analysis (Pearson's correlation) was applied to study the relationship between age, gender, and pedagogical abilities.

\subsection{Research limitations and implications}

The study was limited by both sample size and demographics. It covered a relatively small group of fifth-years, which did not allow drawing conclusions about other groups of students as the level of development and knowledge may be determined by the year of study at the university. To further validate the results, the study can be replicated in more diverse student groups and expanded geography.

\section{Results}

According to the study results, the mean values of the pre-test of the experimental and control groups were within the sample standard deviation and were statistically insignificant ( $p$-value $=0.061$ ). The result of the post-test was opposite insofar as the mean value of the experimental group was 2.41 points higher than that of the control group, which designated a statistically significant difference ( $\mathrm{p}$-value $=0.023$ ). Provided that the post-test mean value for the experimental group was higher than the pretest one $(M=4.81, M=8.32)$, the influence of socio-psychological training was defined as effective for the development of students' communication skills.

The data on the assessment of empathic abilities (Table 2) demonstrated a slight difference in the pre-test mean values in both groups $(\mathrm{M}=4.81, \mathrm{M}=5.01)$. The posttest result indicated a weak statistical significance between the assessment of the level of empathy in the experimental and control groups ( $\mathrm{p}$-value $=0.044)$. The post-test mean values of the ability to empathize for the experimental and control groups were 5.59 and 0.8 higher than pre-test ones. This result shows that the use of socio-psychological training has a minor effect on the development of empathic abilities among students.

Table 2. The assessment of empathic abilities in the sample

\begin{tabular}{|l|c|c|c|c|}
\hline & \multicolumn{2}{|c|}{ Pre-test } & \multicolumn{2}{c|}{ Post-test } \\
\hline & Experimental group & Control group & Experimental group & Control group \\
\hline Average test value & 53.83 & 54.07 & 59.42 & 55.67 \\
\hline Standard deviation & 5.92 & 5.97 & 6.48 & 6.05 \\
\hline p-value & \multicolumn{2}{|c|}{0.068} & \multicolumn{2}{c|}{0.044} \\
\hline
\end{tabular}

The results of the study of the effect of socio-psychological training on the level of pedagogical tact are described in Table 3. According to the data, the pedagogical tact assessments indicated the statistical significance ( $\mathrm{p}$-value $=0.013$ ) of the recorded changes for the experimental and control groups in the post-test. There was a great 
difference in the post-test mean values for the experimental $(M=19.73)$ and the control $(\mathrm{M}=16.34)$ groups. Even though pre-test indicators could hardly be called statistically significant $(\mathrm{p}$-value $=0.142)$ for both groups, the data obtained demonstrated that the influence of socio-psychological training and an increase in the level of pedagogical tact are interdependent.

Table 3. The assessment of the level of pedagogical tact in the sample

\begin{tabular}{|l|c|c|c|c|}
\hline & \multicolumn{2}{|c|}{ Pre-test } & \multicolumn{2}{c|}{ Post-test } \\
\hline & Experimental group & Control group & Experimental group & Control group \\
\hline Average test value & 15.12 & 15.09 & 19.73 & 16.34 \\
\hline Standard deviation & 3.22 & 3.19 & 5.12 & 3.82 \\
\hline p-value & \multicolumn{2}{|c|}{0.142} & \multicolumn{2}{c|}{0.013} \\
\hline
\end{tabular}

Table 4 shows the level of pedagogical abilities before and after the experiment.

Table 4. Data on the level of students' pedagogical abilities obtained before and after the experiment

\begin{tabular}{|l|c|c|c|c|}
\hline \multirow{2}{*}{$\begin{array}{l}\text { The level of students } \\
\text { pedagogical abilities }\end{array}$} & \multicolumn{2}{|c|}{ Pre-test } & \multicolumn{2}{c|}{ Post-test } \\
\cline { 2 - 5 } & $\begin{array}{c}\text { Experimental } \\
\text { group }\end{array}$ & $\begin{array}{c}\text { Control } \\
\text { group }\end{array}$ & $\begin{array}{c}\text { Experimental } \\
\text { group }\end{array}$ & $\begin{array}{c}\text { Control } \\
\text { group }\end{array}$ \\
\hline Low & $33.09 \%$ & $32.74 \%$ & $16.87 \%$ & $28.18 \%$ \\
\hline Average & $51.83 \%$ & $52.11 \%$ & $40.49 \%$ & $55.10 \%$ \\
\hline High & $15.08 \%$ & $15.15 \%$ & $42.64 \%$ & $16.72 \%$ \\
\hline
\end{tabular}

At the initial stage, students of both groups had almost the same level of pedagogical abilities. According to the data obtained before the experiment, approximately $50 \%$ of students had an average level of pedagogical abilities. A relatively small number of students had highly developed pedagogical abilities (15\% of the total number of respondents). As a result of the study, the following dynamics of changes in the level of students' pedagogical abilities can be stated: the number of students with a low level of pedagogical abilities decreased by $16 \%$ in the experimental group and by $5 \%$ in the control group. The number of students with a high level of pedagogical abilities in the experimental group increased significantly $(42.64 \%)$, while in the control group, no notable changes were registered $(16.72 \%)$.

The results of the correlation analysis conducted for the indicators of age, gender, and pedagogical abilities are described in Table 5.

Table 5. Correlation between the age, gender, and pedagogical abilities

\begin{tabular}{|l|c|c|c|}
\hline & Communication abilities & Pedagogical tact & Empathic abilities \\
\hline Gender & 0.01 & 0.12 & 0.19 \\
\hline Male & 0.34 & 0.55 & 0.35 \\
\hline Female & 0.65 & 0.52 & 0.71 \\
\hline
\end{tabular}


The correlation between the age (we considered the average age of the sample $\mathrm{M}=$ 22.7) and gender was determined based on the pre-test results as the level of pedagogical abilities at the beginning of the experiment did not vary greatly. As a consequence, a weak positive correlation between age and pedagogical abilities $(r<0.2)$ as well as a positive correlation between gender and pedagogical abilities ( $r>0.3$ ) was noted. It should be remarked that the correlation between gender and the ability to empathize was rather stronger among females than among males $(0.71$ and 0.35 , respectively). The same applies to communication skills: females $r=0.65$, males $r=0.34$. This result indicates that gender and age do not have a significant impact on the development of pedagogical abilities.

\section{Discussion}

In the course of the study, it was determined that there is a statistical significance between socio-psychological training and pedagogical abilities. Therefore, the null hypothesis can be refuted. At the initial stage of the study, the level of respondents' pedagogical abilities was identical. In general, the post-test results improved by all criteria in the experimental group, and in the control group, the difference was not statistically significant. Undoubtedly, pedagogical abilities belong to individual characteristics of each student. After the preliminary analysis of the initial data, a conscious effort was made to develop communication skills, pedagogical tact, the ability to empathize and understand human experiences, as well as to establish contact with learners. As already noted, a strong focus was given to the communication skills of the teacher. They serve as a means that helps the educator acquire the knowledge to understand the child's mental world, thoughts, and feelings properly, as well as convey the desired idea to others [34]. According to the results of the assessment of communication skills in the experimental group, the level of students' pedagogical abilities changed from average $(\mathrm{M}=4.81)$ to high $(\mathrm{M}=8.32)$.

This indicator allows us to conclude that respondents who took part in socio-psychological training sessions learned to control their emotions, speak in front of the public, listen to other people, and take other points of view into account. It should be noted that even those students who did not have well-developed communication skills at the beginning of the experiment at the end of the training were able to take any role easily, respond to changing situations fast, feel comfortable in a team, and make a positive impression on other people [35]. A similar situation was observed in the assessment of pedagogical tact: in the experimental group, the level of students' pedagogical abilities changed from average $(M=15.22)$ to high $(M=19.73)$. This result indicates that participation in social and pedagogical training increased pedagogical inventiveness in responding to various situations requiring subtle intervention. In addition, the experimental group participants learned to analyze the reasons for the difficulties in the assimilation of educational material as well as to adapt it to the peculiarities of student perception [16]. In view of the preceding, educational innovations must be directed at learners' personal characteristics and academic needs [20]. 
It is a well-known fact that people differ in emotions' perception and expression due to varying characteristics of their personalities. The abilities to emotionally perceive another person, discover his/her inner world, and accept him/her with all thoughts and feelings mainly depend on the nature of personality formation [13]. This implies that the improvement of these abilities requires deeper and more conscious efforts. According to the Student's coefficient in the post-test ( $\mathrm{p}$-value $=0.044$ ), there is an insignificant positive result after the application of the socio-psychological training methodology for the development of empathy in future teachers. Similar studies have shown that when using the methods of socio-psychological training, students develop such pedagogical skills as self-discipline, creativity, oratory, and vocabulary. A certain virtuosity of personality (vivid imagination, the ability to fantasize) is also important for the success of pedagogical activity [36]. As for inborn factors, in some studies, they are considered as anatomical and physiological drives (properties of the nervous system) that underlie the formation of abilities, and the abilities are always the result of progress in a certain activity [37].

\section{Conclusion}

As follows from the conducted examination, at the beginning of the experiment, the groups of respondents were characterized by identical levels of pedagogical abilities. The study revealed a weak positive relationship between age and pedagogical abilities $(\mathrm{r}<0.2)$ and a positive correlation between gender and pedagogical abilities $(r>0.3)$. At the same time, the analysis of the obtained results demonstrated an obvious increase in the level of pedagogical abilities of students who took part in socio-psychological training. Summing up the study findings, it can be inferred that since the post- and pre-test results of the control group differed insignificantly, socio-psychological training sessions were proved to have a favorable effect on the development of students' pedagogical abilities.

\section{Acknowledgment}

This research did not receive any specific grant from funding agencies in the public, commercial, or not-for-profit sectors. The authors declare that they have no conflict of interests.

\section{$7 \quad$ References}

[1] Kunter, M., Kleickmann, T., Klusmann, U., Richter, D. (2013). The development of teachers' professional competence. In Cognitive Activation in the Mathematics Classroom and Professional Competence of Teachers. Springer, Cham, pp. 63-77. https://doi.org/10.1007 1978-1-4614-5149-5_4 
[2] Romanova, G. (2020). The readiness of leading and teaching staff to develop students' sociocultural competence in the inclusive learning environment. Pedagogika, 138(2): 226-243. https://doi.org/10.15823/p.2020.138.13

[3] Lake, V.E., Al Otaiba, S., Guidry, L. (2010). Developing social skills training and literacy instruction pedagogy through service learning: An integrated model of teacher preparation. Journal of Early Childhood Teacher Education, 31(4): 373-390. https://doi.org/10.1080/ $\underline{10901027.2010 .523776}$

[4] Lozano, R., Merrill, M.Y., Sammalisto, K., Ceulemans, K., Lozano, F.J. (2017). Connecting competences and pedagogical approaches for sustainable development in higher education: A literature review and framework proposal. Sustainability, 9(10): 1889. https://doi.org/ $10.3390 / \mathrm{su} 9101889$

[5] Rahman, M.H. (2014). Professional competence, pedagogical competence and the performance of junior high school of science teachers. Journal of Education and Practice, 5(9): 75-80.

[6] Yarkova, T., Cherkasova, I., Timofeeva, A., Cherkasov, V., Yarkov, V. (2017). Preparing teachers to use new media visual communications in education. International Journal of Emerging Technologies in Learning, 12(2): 4-15. https://doi.org/10.3991/ijet.v12i02.6133

[7] Idrus, H., Salleh, R. (2017). Perceived self-efficacy of Malaysian ESL engineering and technology students on their speaking ability and its pedagogical implications. The English Teacher, 37: 61-75.

[8] Schantz, E.A. (2012). Professional training of university students as a holistic educational system. Theory and Practice of Education in the Modern World, 1: 383-386.

[9] Devlin, M., Samarawickrema, G. (2010). The criteria of effective teaching in a changing higher education context. Higher Education Research \& Development, 29(2): 111-124. https://doi.org/10.1080/07294360903244398

[10] Miraja, B., Persada, S., Prasetyo, Y., Belgiawan, P., Redi, A.A.N. (2019). Applying Protection Motivation Theory to understand generation $\mathrm{z}$ students intention to comply with educational software anti piracy law. International Journal of Emerging Technologies in Learning, 14(18): 39-52. https://doi.org/10.3991/ijet.v14i18.10973

[11] Topilina, N.V. (2016). Pedagogical abilities and competencies of parents in modern pedagogical practice. Innovative Science, 2-4(14): 1-7.

[12] Khan, A., Khan, S., Zia-Ul-Islam, S., Khan, M. (2017). Communication skills of a teacher and its role in the development of the students' academic success. Journal of Education and Practice, 8(1): 18-21.

[13] Bouton, B. (2016). Empathy research and teacher preparation: Benefits and obstacles. SRATE Journal, 25(2): 16-25.

[14] Fuentes, A.V.R., Blanco, M.F.A., Ortega, J.L.G., Pérez, I.A.G. (2017). The communication skills of future teachers during their initial training. Multidisciplinary Journal of Educational Research, 7(1): 88-120. https://doi.org/10.17583/remie.2017.2200

[15] Friesen, N., Osguthorpe, R. (2018). Tact and the pedagogical triangle: The authenticity of teachers in relation. Teaching and Teacher Education, 70: 255-264. https://doi.org/10.1016 /j.tate.2017.11.023

[16] Sipman, G., Thölke, J., Martens, R., McKenney, S. (2019). The role of intuition in pedagogical tact: Educator views. British Educational Research Journal, 45(6): 1186-1202. https://doi.org/10.1002/berj.3557

[17] Muste, D. (2016). The role of communication skills in teaching process. In Selection and peer-review under responsibility of the organizing committee of the conference. The European Proceedings of Behavioral and Social Sciences. EpSBS, pp. 430-434. 
[18] Welsh, K.A., Schaffer, C. (2017). Developing the effective teaching skills of teacher candidates during early field experiences. The Educational Forum, 81(3): 301-321. https://doi.org/10.1080/00131725.2017.1314574

[19] Hollins, E.R. (2011). Teacher preparation for quality teaching. Journal of Teacher Education, 62(4): 395-407. https://doi.org/10.1177/0022487111409415

[20] Palupi, B., Subiyantoro, S., Triyanto, T., Rukayah, R. (2020). Creative-thinking skills in explanatory writing skills viewed from learning behaviour: A mixed method case study. International Journal of Emerging Technologies in Learning, 15(1): 200-212. https://doi.org/ $\underline{10.3991 / i j e t . v 15 i 01.11487}$

[21] Negassa, T., Engdasew, Z. (2017). The impacts and challenges of pedagogical skills improvement program at Adama Science and Technology University. International Journal of Instruction, 10(4): 19-38. https://doi.org/10.12973/iji.2017.1042a

[22] Yakovleva, N.O., Yakovlev, E.V. (2014). Interactive teaching methods in contemporary higher education. Pacific Science Review, 16(2): 75-80. https://doi.org/10.1016/ j.pscr.2014.08.016

[23] Huda, M., Maseleno, A., Shahrill, M., Jasmi, K.A., Mustari, I., Basiron, B. (2017). Exploring adaptive teaching competencies in big data era. International Journal of Emerging Technologies in Learning, 12(3): 68-83. https://doi.org/10.3991/ijet.v12i03.6434

[24] Sakenov, D., Kushnir, Y.V., Shnaider, Y., Abdulkhamidova, D.Z. (2012). Preparation of students of higher education institution for professional activity in the course of studying of pedagogical disciplines. World Applied Sciences Journal, 19(10): 1431-1436.

[25] Enyashina, N.G., Gridneva, S.V., Khudyakova, T.L., Gridyaeva, L.N., Pozharskay, E.L., Deberdeeva, N.A. (2017). A social and psychological training course as a form of teaching in the process of the students' professional education at a higher education institution. Eurasian Journal of Analytical Chemistry, 12(5b): 753-763. https://doi.org/10.12973/ ejac. $2017.00208 \mathrm{a}$

[26] Merzon, E. (2011). Educational environment as factor of formation of professional competence of students of pedagogical university. Young Scientist, 10(2): 170-172.

[27] Nurmanov, A.T. (2015). Technological aspects of students training to effective communication at pedagogical university. Theoretical \& Applied Science, 12(32): 81-86. https://doi.org/10.15863/tas.2015.12.32.15

[28] Seligman, M.E.P., Ernst, R.M., Gillham, J., Reivich, K., Linkins, M. (2009). Positive education: Positive psychology and classroom interventions. Oxford Review of Education, 35(3): 293-311. https://doi.org/10.1080/03054980902934563

[29] Huda, M., Anshari, M., Almunawar, M.N., Shahrill, M., Tan, A., Jaidin, J.H., Daud, S., Masri, M. (2016). Innovative teaching in higher education: The big data approach. The Turkish Online Journal of Educational Technology, 1: 1210-1216.

[30] Lodico, M.G., Spaulding, D.T., Voegtle, K.H. (2010). Methods in educational research: From Theory to Practice (Vol. 28). John Wiley \& Sons, London.

[31] Palermo, T.M., Janicke, D.M., McQuaid, E.L., Mullins, L.L., Robins, P.M., Wu, Y.P. (2014). Recommendations for training in pediatric psychology: Defining core competencies across training levels. Journal of Pediatric Psychology, 39(9): 965-984. https://doi.org/ $\underline{10.1093 / \text { jpepsy/jsu015 }}$

[32] Snyder, M. (1974). Self-monitoring of expressive behavior. Journal of Personality and Social Psychology, 30(4): 526-537. https://doi.org/10.1037/h0037039

[33] Mehrabian, A., Epstein, N. (1972). A measure of emotional empathy. Journal of Personality, 40(4): 525-543. 
[34] Webb, M., Cox, M.J. (2007). A review of pedagogy related to information and communications technology. Technology, Pedagogy and Education, 13(3): 235-286. https://doi.org/ $10.1080 / 14759390400200183$

[35] Arquero, J.L., Fernández-Polvillo, C., Hassall, T., Joyce, J. (2017). Relationships between communication apprehension, ambiguity tolerance and learning styles in accounting students. Revista de Contabilidad-Spanish Accounting Review, 20(1): 13-24. https://doi.org/ 10.1016/j.rcsar.2015.10.002

[36] From, J. (2017). Pedagogical digital competence--between values, knowledge and skills. Higher Education Studies, 7(2): 43.

[37] Delima, N. (2017). A relationship between problem solving ability and students' mathematical thinking. Infinity Journal, 6(1): 21-28. https://doi.org/10.22460/infinity.v6i1.231

\section{Authors}

Araily Shakirova is Master of Pedagogical Sciences at the Department of Developmental Pedagogy and Psychology at the Zhetysu University named after I. Zhansugurov, Samal microdistrict, building 28, apartment 42, 040000 Taldykorgan, Kazakhstan. She studies pedagogy and psychology (shakirovaara@rambler.ru).

Galina Romanova is a Candidate of Pedagogics at the Department of Methods of Education and Additional Education at the Academy of Social Management, Murmansk proezd, d. 22, sq. 23, 129075 Moscow, Russian Federation. Her scientific work specialized at studying retraining and advanced training of teaching staff; theory and technology of education; theory and technology of teaching etc.

Svetlana Vlasova is a senior teacher of the Department of I-11 Foreign Language for Aerospace Specialties at the Moscow Aviation Institute, Novaya Bashilovka street, building 4, apartment 13, 125040 Moscow, Russian Federation. She is interested in study of pedagogics.

Article submitted 2021-04-15. Resubmitted 2021-05-24. Final acceptance 2021-05-24. Final version published as submitted by the authors. 